\title{
BEST OF BOTH WORLDS?: USING BLENDED LEARNING IN A PROFESSIONAL LIBRARIAN PREPARATION PROGRAM
}

\section{Summary}

Librarianship in the United States is a career path that requires a master's degree for professional advancement and so is often begun by students later in life, when they are no longer as free to concentrate wholly on education as those students just completing their bachelor's degrees. Library students may currently work in libraries in non-professional roles or may hold full-time jobs in other fields, and both groups may also have additional family responsibilities that limit their ability to return to their studies on a full-time basis. Accordingly, students are attracted to educational programs that offer more flexibility with time or geographical location than many traditional faceto-face programs are able to offer.

Emporia State University's School of Library and Information Management has been on the forefront of developing high-quality professional education programs for nontraditional graduate students for over 25 years. The School currently enrolls over 350 master's degree students at two locations in Kansas, and at four other locations in Colorado, Oregon, South Dakota and Utah. Each location employs a cohort system so students enjoy a strong support network for the two years they spend in the program, and classes are taught in what has developed over the past 25 years from a completely face-to-face instructional model to a blended model that employs both face-to-face and online instruction.

The faculty work collaboratively in themed communities of practice to exploit the benefits of each delivery mode. Work that is easily accomplished by the students individually is assigned through the online portion, as is work in collaborative groups, where the online tools can facilitate both synchronous and asynchronous communication. Work that requires real-time interaction by the students and the professor is assigned to one of the two face-to-face intensive weekends of instruction that are a feature of every core course.

Admissions MU 105, 1 Kellogg Cir, Emporia, KS 66801, USA

asmith37@emporia.edu 
The provision of both types of learning experience within the professional program provides many benefits to the students, including a strong sense of cohort identity and corresponding support, resulting in high on-time graduation rates and positive program outcomes. Faculty also benefit from the blended program, which aids greatly in the teaching of certain professional skills and concepts. However, there are corresponding disadvantages from the faculty perspective, including the requirement to travel twice a semester for each course, scheduling difficulties which can affect the sequencing of course content, and problems with balancing the amount of contetn within the course itself.

Key words: library science education, blended learning, distance learning, professional education

Librarianship in the United States is a career path that requires a master's degree for professional advancement (American Library Association, n.d.) and is often undertaken as a second or third career, when students are no longer as free to concentrate wholly on education as those students just completing their bachelor's degrees. Library students may currently work in libraries in non-professional roles or may hold full-time jobs in other fields, and both groups may also have additional family responsibilities that limit their ability to return to their studies on a full-time basis. Accordingly, students are attracted to educational programs that offer more flexibility with time or geographical location than many traditional face-to-face programs are able to offer.

Emporia State University's School of Library and Information Management was founded in 1902 and has been on the forefront of developing high-quality professional education programs for non-traditional graduate students for over 25 years. The School currently enrolls over 350 master's degree students at two locations in Kansas, and at four other locations in the United States in Colorado, Oregon, South Dakota and Utah. Historically, these locations came about because the universities offering library science education closed their departments and programs or library science education was never available in these locations, except through completely online programs or not at all, in the days before the internet (School of Library and Information Management, n.d. -b). In the early cases, the State Librarian in the state in question requested Emporia to come and provide library science education and, as more universities abolished their library science education, Emporia's reach expanded. 


\section{Program Structure}

Each location employs a cohort system where students begin the program together in a cohort group and move through the program at the same pace, graduating together at the end, so students enjoy a strong support network for the two years they spend in the program. Classes are taught in what has developed over the past 25 years from a completely face-to-face instructional model to a blended model that employs both face-to-face and online instruction. Each location begins a new cohort every year, with three locations starting new students in August, and three locations starting new students in January (School of Library and Information Management, n.d. -c).

There are seven core classes that are required of all students in the program, and these are all taught in the blended format and are taken in cohort groups. Students are at liberty to choose other courses to complete their degrees based on their interests and professional goals, and these are all taught fully online, as students from all cohorts may enroll in these courses when they wish.

The faculty work collaboratively in themed communities of practice to exploit the benefits of each delivery mode. Our communities of practice are comprised of all the teachers who are responsible for either the same course or for related courses (for example the courses in organization of information, the cataloging course, the metadata courses, and the indexing course.) This collaboration includes the creation of Course Learning Outcomes that are standard for each course, proposed by the Community of Practice and approved by the whole faculty. There is also one common assessment for each core course, again developed by the Communities of Practice and approved by the faculty as a whole. This ensures that no matter who is teaching the course and in which location, students are studying the same material and striving toward the same goals, as well as giving a way to measure standards of achievement across all cohorts and from yearto year. (Each faculty member is free to structure the course as he or she prefers, to select different textbooks and supporting assignments, and to create an effective learning environment as long as the one common assessment is included and the students are working toward the same learning outcomes.) Work that is easily accomplished by the stu- 
dents individually is assigned through the online portion, as is work in collaborative groups, where the online tools can facilitate both synchronous and asynchronous communication. Work that requires real-time interaction by the students and the professor is assigned to one of the two faceto-face intensive weekends of instruction that are a feature of every core course (School of Library and Information Management, 2015).

The provision of both types of learning experience within the professional program provides many benefits to the students, including a strong sense of cohort identity and corresponding support, resulting in high ontime graduation rates and positive program outcomes. Faculty also benefit from the blended program, which aids greatly in the teaching of certain professional skills and concepts. However, there are corresponding disadvantages from the faculty perspective, including the requirement to travel twice a semester for each course, scheduling difficulties which can affect the sequencing of course content, and problems with balancing the amount of content within the course itself.

\section{Travel}

The face-to-face weekends require each faculty member teaching a class weekend to travel to the class location. Obviously travel in Emporia is not an issue, and Kansas City is only an hour and a half drive away. However travel to Sioux Falls, South Dakota (400 miles), Denver, Colorado (550 miles), Salt Lake City, Utah (1000 miles), and Portland, Oregon (1800 miles) requires a drive to an airport (one and a half or two and a half hours, depending on the airport), one or more flights to reach the destination city and another hour or more to reach the hotel. This means that for out-of-state teaching weekends, faculty members must travel on a Thursday,prepare and teach 3 hours on a Friday evening, then teach for 7 hours on Saturday and travel home on Sunday. This makes for a very intensive and exhausting four days. For each core course taught in the blended method, there are two teaching weekends per semester.

Load

A typical faculty load in a semester would involve one blended class near home(Emporia or Kansas City), one further away (Colorado, Oregon, South Dakota or Utah), and one fully online class. The online classes are 
open to students from all cohorts, so geographical location is not a limiting factor (School of Library and Information Management, 2015). This also means that faculty are engaged in both blended and fully online teaching at the same time, which requires a constant balancing of the different techniques needed to operate successfuly in each classroom environment.

Each cohort location is staffed with a full time regional director, who is responsible for all administration at the remote location, and also serves as the academic advisor for all students in that cohort School of Library and Information Managemnet, n.d. -a). While this gives the student a great deal of support and continuity, it does distance the faculty from the student population, and many students graduate from our program having had only one class with each of the faculty members. Faculty members can also experience the strange sensation of attending commencement cermonies and watching an entire cohort graduate, none of whom they have ever taught.

Over the years there has been pressure from various people and entities within the university to move to a completely online program. This has many immediate benefits at the university level from the money saved on travel budgets, to the days saved by the faculty members who no longer have to travel. However, the faculty have always resisted this, as although the blended teaching places a considerable strain on the teachers, they are unwilling to give up this direct contact with students that provides many benefits in the teaching process. Their belief is that there is tremendous benefit in the shared classroom experience that cannot be duplicated in the online environment, and while there are activities that can easily be accomplished online, there are others, particularly involving ethical issues, controversial topics and activities that require extensive debriefings, that are best conducted in a live classroom where there is direct and unmediated exchange between the teacher and the students.

The immediate savings do not take into account the fact that many students choose our program, which is not the least expensive available, specifically because of the cohort model, and the face-to-face classes. Students do not necessarily want to take their whole degree online through mediated communication. Employers also note the benefits of students who have been prepared in a collaborative, professional environment, rather than one that has been either completely individual or totally online. 
Different skill sets are now being identified as essential to the library profession, with recent surveys, such as that of Simmons College SLIS (2017), showing the equal or in some cases greater importance of communication skills, writing ability, teamwork, customer service skills, and teamwork over traditional information-seeking and information evaluation skills.

Maintaining a schedule of classes with this many variables is complex. In any 16-week semester during the fall or spring, there will be at least three new cohorts requiring the first two classes in the required core (and some of these cohorts may be large enough to require the teaching to be split into two sections), three cohorts beginning their second year requiring the appropriate core class, as well as six cohorts, three in their first year and three in their second, who require the appropriate core classes. As there are only a limited number of weekends in a semester, a number made more limited by holidays and university policies, it is immensely complicated to schedule everything to ensure that class weekends are balanced for students and for the teaching faculty.

This can also present difficulties to teachers, as the exact time the face-to-face weekends fall within the semester can change from semester to semester, so a course that was structured and taught one semester with the teaching weekends in, for example, weeks 5 and 13 may have to be taught the following semester with the teaching weekends in weeks 1 and 8. It also frequently occurs that a teacher has two sections of the same course, but with radically different positioning of the face-to-face weekends within the same semester. This can result in having to teach the same course and the same course content but with different sequencing within a semester for two sections of the same course, in order to ensure students are prepared for the activities and content of the face-to-face weekends, in order to take full advantage of the benefits of the different delivery systems.

This does have the benefit of ensuring that the various faculty members are closely examining their courses every semester, looking for ways to improve the learning experience and experimenting with different delivery systems and content sequencing, which feeds back into the communities of practice and can result in course improvement in both that specific part of the currriculum and across the curriculum as a whole, but it can also be extremely challenging to teach in this environment, because 
of the demands it places on the teacher's time and creativity, and the fact that no course is an exact replica of last time it was taught. Each location will also see a rotation of teachers, so the professors who taught the two courses in the first semester in Emporia one year will likely not be the two who teach those courses the following year, so although they may be assigned to teach that course on a weekend schedule they taught two years before, they will most likely have taught the course in in three other semesters with varying loacations and weekend schedules in between.

For the foreseeable future, we are committed to continuing with our blended learning model, as we believe it offers the best compromise between the needs of the non-traditional learners and providing the best professional library education we can. As our student population changes we may discover that students no longer expect face-to-face interaction with their professors, however this assumption that all young people are happy with digitally-mediated communication only is proving not to be the case, in the same way that many younger people are rejecting ebooks for the print variety, despite the vision-casters telling us ten years ago that the print book was dead.

This type of teaching assignment requires a great deal of support from university administration and support personnel, who do not always fully understand the complexity of the system, the additional demands made on the teaching faculty by the use of dual teaching methods, and the resources required to maintain such a program at a high level, as it is so different from the regular face-to-face teaching assignments of the majority of faculty. The fact that much of the activity is invisible to the university, taking place online, on weekends, and off campus and out of state simply exacerbates the problem. More education and advocacy needs to take place to ensure that programs of this type, that are of great benefit to non-traditional students, continue to be available. 


\section{References}

American Library Association (n.d.). Become a librarian. Retrieved October 16, 2018 from http://www.ala.org/educationcareers/libcareers/become

School of Library and Information Management. (n.d. -a). Earn your Master of Library Science in Emporia, Kansas. Retrieved October 16, 2018 from https://www.emporia.edu/slim/documents/other/emporia-flyer.pdf

School of Library and Information Management. (n.d. -b). History: 1900s-1960s. Retrieved from https://www.emporia.edu/slim/about/history.html

School of Library and Information Management. (n.d. -c). Master of Library Science. Retrieved September 26, 2018 from https://www.emporia.edu/slim/programs/ master-of-library-science/

School of Library and Information Management. (2015). Comprehensive review for accreditation. Retrieved from https://www.emporia.edu/slim/documents/other/ACCREDITATION+2015+FINAL+VERSION+8+24+2015+Rev+10+19+2015. pdf?language_id=1

Simmons College SLIS. (2017). Skills and knowledge survey executive summary. Retrieved from http://slis.simmons.edu/blogs/unbound/files/2017/05/ExecutiveSummary-for-release.pdf

\section{Ендрју Смит}

Емпориа Универзитет

\section{НАЈБОљЕ ОД ОБА СВЕТА?: \\ КОРИШЋЕЊЕ МЕШОВИТОГ УЧЕЊА У ПРОГРАМИМА КРЕИРАНИХ ОД СТРАНЕ СТРУЧНОГ БИБЛИОТЕКАРА}

\section{Сажетак}

Библиотекарство у Сједињеним Америчким Државама представља пут који захтева магистарски степен стручног усавршавања и тако се често започиње од стране студената, касније у животу, када више нису слободни да се у потпуности сконцентришу на образовање, као они који управо завршавају своје основне студије. Студенти библиотекарства могу радити у библиотекама у непрофесионалним улогама или могу обављати редовне послове у другим областима,, а обе групе могу имати и додатне породичне одговорности које ограничавају њихову способност да се врате студирању са пуним радним временом. Сходно томе, студенте привлаче 


\section{Култура универзитета и филологија}

едукативни програми који нуде више флексибилности (време или географска локација) него што многи формални програми могу да понуде.

Школа за библиотекарство и информациони менаџмент на Емпориа Универзитету је на челу са развојем висококвалитетних програма стручног образовања за студенте који поред традиционалног учења, користе и технологију, већ више од 25 година. Школа тренутно уписује више од 350 студената магистра на две локације у Канзасу и на још четири локације у Колораду, Орегону, Јужној Дакоти и Јути. Свака локација користи систем kohort тако да студенти уживају у снажној мрежи подршке током две године које проведу у програму, а долазеће генерације се подучавају у ономе што се развијало у протеклих 25 година од традиционалног образовног модела лицем у лице, до мешовитог модела који повезује две методе - и лицем у лице и онлајн инструкције.

Задаци се додељују путем онлајн комуникације, као што је рад у заједничким групама, где онлајн алати могу олакшати и истовремену, али и временски неусклађену комуникацију. Рад који захтева интеракцију у реалном времену од стране студената и професора одређен је на један од два интензивна викенда наставе лицем у лице који су карактеристични за сваки курс.

Пружање оба типа искуства у учењу у оквиру професионалног програма пружа многе предности студентима, укључујући снажан оceћaj kohort идентитета и одговарајућу подршку, што резултира високим степеном завршетка школовања и позитивним програмским исходима. Факултет такође има користи од мешовитог програма, који значајно помаже у настави одређених професионалних вештина и концепата. Међутим, постоје недостаци, укључујући и захтев за путовање два пута по семестру за сваки курс, распоређивање потешкоћа које могу утицати на уређење и садржај курс, као а и проблеми са балансирањем количине садржаја у самом курсу.

Кључне речи: библиотечка наука, мешовито учење, учење на даљину, стручно образовање 